\title{
Can reduced tillage sustain sugarcane yield and soil carbon if straw is removed?
}

\author{
Sarah Tenelli ${ }^{1,2} \cdot$ Ricardo de Oliveira Bordonal $^{1}$ • Leandro Carneiro Barbosa ${ }^{1}$ • João Luis Nunes Carvalho ${ }^{1}$
}

Published online: 26 June 2019

(C) The Author(s) 2019

\begin{abstract}
Straw removal for bioelectricity, cellulosic ethanol, or other bio-products has become a common practice in Brazilian sugarcane areas, but long-term effects on soil organic carbon (SOC) and yield are unknown. Our objective was to quantify tillage intensity and removal levels on SOC stocks and sugarcane yield on contrasting edaphoclimatic conditions in Brazil. Conventional tillage$\mathrm{CT}$ and reduced tillage-RT coupled with three straw removal levels (none-NR; moderate-MR; total- $\mathrm{TR}$ ) were combined to create six treatment combinations: CTNR, CTMR, CTTR, RTNR, RTMR, and RTTR, respectively. Sugarcane yield was measured annually and soil samples to a depth of $40 \mathrm{~cm}$ were collected and analyzed before and after 5 years of treatments. Neither tillage practices nor straw removal significantly affected sugarcane yield on sandy loam soil, but CTMR, CTTR, and RTTR showed substantial yield reductions on clayey soil. SOC stocks for RTNR increased by as much as $1.64 \mathrm{Mg} \mathrm{ha}^{-1} \mathrm{year}^{-1}$ on clayey soil, while CTMR and CTTR favored depletion of SOC stocks on both soils. Overall, each Mg of straw returned to the soil increased SOC stock by $95 \mathrm{~kg} \mathrm{ha}^{-1}$ for clayey soil under both tillage practices and $55 \mathrm{~kg} \mathrm{ha}^{-1}$ for sandy loam under the CT system. Furthermore, straw removal decreased microbial biomass $\mathrm{C}$ and b-glucosidase activity. These findings suggest that the adoption of RT attenuates the adverse impacts of straw removal on SOC stocks while ensuring sugarcane yields for a more sustainable bioenergy production in Brazil.
\end{abstract}

Keywords Tillage systems · Saccharum spp. · Soil enzymatic activity $\cdot$ Microbial biomass carbon $\cdot$ Soil organic matter $\cdot$ Crop residues

\section{Introduction}

Sustainable management practices have a major effect on sustaining soil organic carbon (SOC) while providing renewablebased energy resources to biofuel feedstocks and contribute to carbon (C) sequestration from the atmosphere [1]. To meet the international commitments assumed at the Paris Convention

Electronic supplementary material The online version of this article (https://doi.org/10.1007/s12155-019-09996-3) contains supplementary material, which is available to authorized users.

João Luis Nunes Carvalho

joao.carvalho@ctbe.cnpem.br

1 Brazilian Biorenewables National Laboratory (LNBR), Brazilian Center of Energy and Material Research (CNPEM), Giuseppe Maximo Scolfaro Street, 10000, Campinas, SP 13083-100, Brazil

2 Interdisciplinary $\mathrm{PhD}$. Program in Bioenergy, University of Campinas (UNICAMP), Rua Monteiro Lobato, 80, Cidade Universitária, Campinas, SP 13083-862, Brazil of the Parties (COP 21) in supplying global targets for bioenergy, the Brazilian government intends to increase ethanol production by 50 billion liters per year by 2030 [2], which is $79 \%$ higher than it was produced in 2015. In the view of biofuel programs that can help reduce the $\mathrm{C}$ footprint of ethanol, Brazil stands out already as a low $\mathrm{C}$ economy, including today an energy mix of $40 \%$ of renewables and cogeneration of electricity from biomass [3]. Brazil is the major producer of sugarcane (Saccharum spp.) with a production of 660 million tons from a cultivated area of 8.6 million ha in the 2018/2019 season [4].

Sugarcane is a crop that is grown in a 5- to 6-year cycle of yearly harvests. With the historical replacement of sugarcane burning prior to harvest, a significant amount of straw (i.e., $10-20 \mathrm{Mg} \mathrm{ha}{ }^{-1}$ of dry mass) is now deposited on the soil surface annually [5]. Sugarcane straw (also known as trash) consists mainly of green tops and dry leaves [5]. The highenergy potential of sugarcane is very competitive in relation to fossil fuels and can be a consistent source of replacement to mitigate greenhouse gas (GHG) emissions [6]. The sugarcane stalk compartment is the raw material used for $1 \mathrm{G}$ ethanol 
production, in which from the juice is produced sugar and ethanol and the remainder of bagasse is a source currently used for bioelectricity generation. The straw compartment represents one-third of the total sugarcane energy that can be potentially used for bioenergy production [7]. Because of the possible conversion of sugarcane straw into cellulosic biofuels, bioelectricity, and other bio-products, new approaches to straw biomass management have emerged in Brazilian sugarcane fields [8]. However, a lot of controversy remains about the amount of straw that can be sustainably removed to sustain soil ecosystem services [9], which is highly variable and is a function of multiple aspects including crop aging, soil characteristics, climatic conditions, and agriculture practices [10].

Maintaining sugarcane straw in the field supports soil biota as a source of nutrients, shelter, and better microclimate conditions, which promote increases in microbial biomass [11]. Indiscriminate removal of sugarcane straw from the field can intensify the risk of soil erosion [12] and has detrimental effects on numerous soil quality indicators [9], including SOC stocks [10,13,14], microbial activity [11, 15], soil structure [16], plant-nutrient recycling [17], weed infestation [5], soil thermal regulator, and water storage $[18,19]$. On the other hand, keeping excessive amounts can retard ratoon tillering in some specific regions [20], promote an ideal microclimate for pests and diseases development [7], and increase $\mathrm{N}_{2} \mathrm{O}$ emissions to the atmosphere [21]. Such a concern associated with the straw management challenges is not restricted to sugarcane straw in Brazil but is rather a subject of research emerging in other locations using corn stover in the USA [22] and wheat in Europe [23].

Although the use of straw represents a valuable asset for bioenergy production and could provide short-term economic gains for farmers, the removal of this crop residue may decrease SOC stocks, thus reducing part of the environmental and agronomic benefits. Recent studies have indicated that sugarcane straw is an important source of $\mathrm{C}$ to the soil, and consequently, the indiscriminate removal of this crop residue will result in depletion of SOC stocks [10, 14, 24], which can negatively affect the GHG balance of sugarcane ethanol production [14].

In most areas under sugarcane production in Brazil, the straw remains on the soil surface and conventional tillage (CT) is still performed during the crop replanting period, and therefore, this management can potentially reduce the benefits of straw retention in SOC accretion [25]. Reduced tillage (RT) plays an essential role as an environmental and economical viable management [26] to reduce GHG emissions associated with tillage operations in the sugarcane mechanized system [27]. In this context, a transition to conservationist management practices such as the RT system could be a feasible management target to enhance SOC sequestration in sugarcane fields [28].
Losses of SOC stocks play an important role for monitoring land and soil degradation [29]. Monitoring SOC stocks is critical to underpin strategies of management for sustaining key soil functions [30], so that the integrated use of RT coupled with straw removal should be further investigated as a management target to potentially offset SOC losses [24]. Although recent studies modeled SOC changes induced by straw removal in Brazilian sugarcane fields [13, 14], there are no studies assessing in-field SOC changes induced by levels of straw removal in sugarcane areas under different tillage systems in Brazil. This study was based on the hypothesis that (i) the removal of straw in CT management intensifies SOC losses and does not reflect in higher sugarcane yield relative to the RT system and (ii) the RT under moderate and no-removal of straw is a management target for enhancing SOC stocks and sustaining sugarcane yields over the crop cycle. This study was designed to evaluate the changes in SOC stocks affected by contrasting straw removal levels and tillage systems in two sugarcane fields with different soil textures in south-central Brazil. Our focus was also to quantify the impacts of straw removal on soil microbial biomass $\mathrm{C}$ and $\beta$-glucosidase activity under the RT system. The specific objective was to assess the potential of RT as a management strategy to offset the adverse effects of straw removal on SOC stocks and ensure a viable sugarcane yield.

\section{Material and methods}

\section{Characterization of study areas}

Two field trials were installed in December 2012 in commercial sugarcane farms located in Quatá, São Paulo (SP) state, and Quirinópolis, Goiás (GO) state. According to Soil Survey Staff [31], Quatá/SP has an arenic Kandiudult soil with sandy loam texture and a climate classified as $\mathrm{C}^{1} \mathrm{wA}^{\prime} \mathrm{a} \mathrm{a}^{\prime}$, which is a dry to sub-humid climate with moderate hydric excess in the summer [32]. Quirinópolis/GO has a Rhodic Eutrudox soil with clayey texture and a climate defined as B1wA'a', which is a humid climate with moderate water deficiency in the winter. Descriptions of land use and management changes in both areas before the experiment setup and the soil physical and chemical characterization in 2012 are presented in Table 1.

\section{Experimental design and treatments}

Before the field experiments setup (October 2012), each location was under the fifth sugarcane ratoon cycle, and thus it was submitted to a renovation period by spraying glyphosate $(6 \mathrm{~L}$ $\left.\mathrm{ha}^{-1}\right)$, followed by applications of lime $\left(2 \mathrm{Mg} \mathrm{ha}^{-1}\right)$ and gypsum $\left(1 \mathrm{Mg} \mathrm{ha}^{-1}\right)$. A cover crop with sunn hemp (Crotalaria spectabilis) was planted in December 2012 at a rate of $25 \mathrm{~kg}$ seed ha ${ }^{-1}$ and herbicides were used to desiccate it $\left(5 \mathrm{~L} \mathrm{ha}^{-1}\right.$ of 
Table 1 Soil characterization of the sites before experiments establishment in 2012 in sandy loam soil and clayey soil

\begin{tabular}{|c|c|c|}
\hline Sites description & Sandy loam soil & Clayey soil \\
\hline Location (city/state) & Quatá/São Paulo & Quirinópolis/Goiás \\
\hline Geographic coordinates & $22^{\circ} 14^{\prime} \mathrm{S} ; 50^{\circ} 42^{\prime} \mathrm{W}$ & $18^{\circ} 32^{\prime} \mathrm{S} ; 50^{\circ} 26^{\prime} \mathrm{W}$ \\
\hline Elevation (m) & 541 & 460 \\
\hline Mean annual precipitation (mm) & 1254 & 1520 \\
\hline Mean annual temperature $\left({ }^{\circ} \mathrm{C}\right)$ & 20.8 & 22.5 \\
\hline Previous land use & Pasture & Pasture \\
\hline Conversion of pasture to sugarcane & 1995 & 2006 \\
\hline Adoption of burned harvesting & $1995-2009$ & - \\
\hline Adoption of green mechanized harvesting & 2009 & 2006 \\
\hline \multicolumn{3}{|l|}{ Chemical attributes $(0-40 \mathrm{~cm})^{\mathrm{a}}$} \\
\hline $\mathrm{pH} \mathrm{CaCl}{ }_{2}$ & 4.8 & 5.6 \\
\hline $\operatorname{SOM}\left(\mathrm{g} \mathrm{dm}^{-3}\right)$ & 12 & 46 \\
\hline $\mathrm{P}\left(\mathrm{mg} \mathrm{dm}^{-3}\right)$ & 15 & 8 \\
\hline $\mathrm{K}\left(\mathrm{mmol}_{\mathrm{c}} \mathrm{dm}^{-3}\right)$ & 0.4 & 3.7 \\
\hline $\mathrm{Ca}\left(\mathrm{mmol}_{\mathrm{c}} \mathrm{dm}^{-3}\right)$ & 12 & 38 \\
\hline $\operatorname{Mg}\left(\mathrm{mmol}_{\mathrm{c}} \mathrm{dm}^{-3}\right)$ & 3.6 & 11 \\
\hline $\mathrm{CEC}\left(\mathrm{mmol}_{\mathrm{c}} \mathrm{dm}^{-3}\right)$ & 32 & 75 \\
\hline $\mathrm{BS}(\%)$ & 48 & 71 \\
\hline \multicolumn{3}{|l|}{ Physical attributes $(0-40 \mathrm{~cm})^{\mathrm{b}}$} \\
\hline \multicolumn{3}{|l|}{ Clay/silt/sand content $\left(\mathrm{g} \mathrm{kg}^{-1}\right)$} \\
\hline $0-10 \mathrm{~cm}$ & $87 / 60 / 853$ & $547 / 186 / 267$ \\
\hline $10-20 \mathrm{~cm}$ & $108 / 60 / 832$ & $561 / 190 / 249$ \\
\hline $20-40 \mathrm{~cm}$ & $142 / 57 / 801$ & $580 / 195 / 225$ \\
\hline \multicolumn{3}{|l|}{ Soil bulk density $\left(\mathrm{Mg} \mathrm{m}^{-3}\right)$} \\
\hline $0-10 \mathrm{~cm}$ & 1.76 & 1.37 \\
\hline $10-20 \mathrm{~cm}$ & 1.77 & 1.29 \\
\hline $20-40 \mathrm{~cm}$ & 1.76 & 1.23 \\
\hline
\end{tabular}

$S O M$, soil organic matter; $C E C$, cation exchange capacity; $B S$, base saturation. ${ }^{\mathrm{a}, \mathrm{b}}$ Soil physical and chemical analyses according to Van Raij et al. [33] and Blake and Hartge [34] glyphosate, 1.2 $\mathrm{L} \mathrm{ha}^{-1}$ of 2,4-D, and $0.5 \mathrm{~L} \mathrm{ha}^{-1}$ of triomax) at the flowering stage in March/April 2013. After 15 days, two treatments composed of tillage systems were established in a randomized block design with four repetitions. The tillage systems are described as follows: (1) reduced tillage (RT), in which soil preparation was not performed and only planting furrows was opened at a 0.30 -m soil depth over the cover crop biomass using a 2-row planter with spacing of $1.5 \mathrm{~m}$; (2) conventional tillage (CT), which was characterized by cross subsoiling using a subsoiler of 5 rows at $0.40-\mathrm{m}$ depth spaced $0.5 \mathrm{~m}$, a light hydraulic harrowing with harrow of 36 disks at $0.20 \mathrm{~m}$ and the opening of planting furrows at $0.30-\mathrm{m}$ depth; all practices were performed using a $4 \times 4$ tractor of $220 \mathrm{cv}$. More details of tillage systems are found in Fig. 1. Sugarcane was planted manually 1 day after tillage practices by placing 15-20 buds per meter using the RB96-6928 variety. Each plot was composed of 10 sugarcane rows at $1.5 \mathrm{~m}$ spacing with 10 $\mathrm{m}$ long by $15 \mathrm{~m}$ wide. At the base of the planting furrow, fertilizers were applied at a rate of $40 \mathrm{~kg} \mathrm{~N} \mathrm{ha}^{-1}, 125 \mathrm{~kg}$ $\mathrm{P}_{2} \mathrm{O}_{5} \mathrm{ha}^{-1}$ and $125 \mathrm{~kg} \mathrm{~K}_{2} \mathrm{O} \mathrm{ha}^{-1}$.
Thereafter the harvesting of plant-cane cycle in June 2014, three additional treatments of straw management were established in a randomized block design with four repetitions. The straw management comprised of the following removal levels: (i) no-removal-NR; (ii) moderate removalMR (50\% of total produced), and (iii) total remova-TR. Therefore, the experimental design consisted of six treatment combinations, namely CTNR, CTMR, CTTR, RTNR, RTMR, and RTTR. Straw removal levels were established based on the amount of straw produced at each site, which was estimated randomly inside the field trial using a square $\left(0.25 \mathrm{~m}^{2}\right.$ at six points per area), weighed, and the moisture was quantified using the sensor AL-104 Agrologic $₫$ with E-831 Electrode to assess the results in dry basis. The MR plots were divided into two symmetrical sections, one which all the straw was completely removed and the straw from the other part was uniformly distributed over both sections to yield 50\% straw cover across the entire plot. In the TR plots, all straw removed. Same proceedings were performed for the subsequent ratoons each year (Fig. 2). The total amount of straw (in dry basis) 
Fig. 1 Description of conventional tillage-CT and reduced tillage-RT characteristics adopted in the field experiment. $\square$ - dark gray color represents soil disturbed during soil tillage practices; $\square$ - black represents soil disturbed by soil tillage practices plus planting furrow opening; $\square$ - light gray represents soil disturbed only by planting furrow opening, and $\square$ - white is soil undisturbed

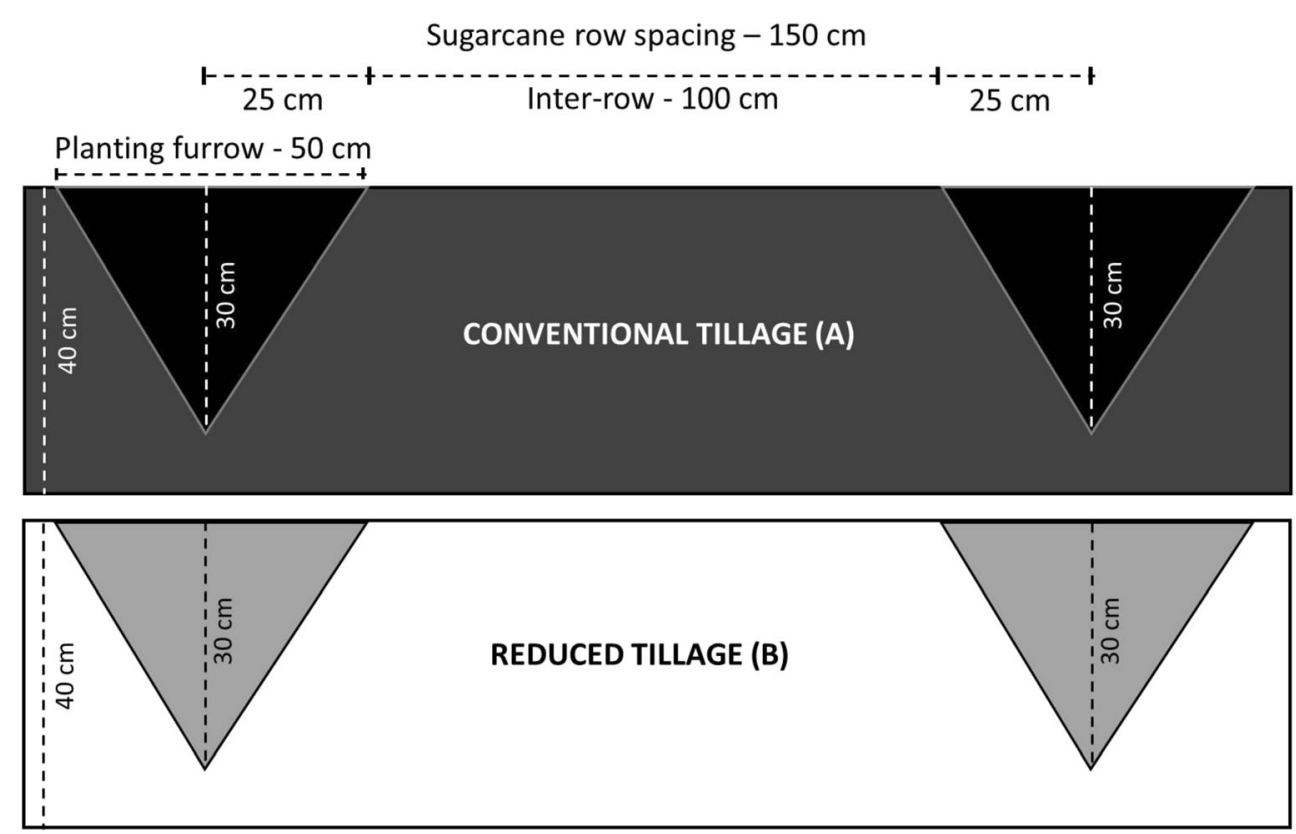

produced in plant-cane first, second, and third ratoons in the two sites were as follows: $16.5,17.2,17.2$, and $13.4 \mathrm{Mg} \mathrm{ha}^{-1}$ in the clayey soil and 9.2, 12.6, 7.5, and 7.5 Mg ha ${ }^{-1}$ in sandy loam soil. The fertilization of sugarcane ratoon cycles was applied 60 days after each harvest, above the straw layer and $10 \mathrm{~cm}$ away from crop row, using the following sources: ammonium nitrate $\left(32 \% \mathrm{~N}\right.$, rate of $\left.120 \mathrm{~kg} \mathrm{~N} \mathrm{ha}^{-1}\right)$ and potassium chloride $\left(60 \% \mathrm{~K}_{2} \mathrm{O} ; 120 \mathrm{~kg} \mathrm{~K}_{2} \mathrm{O} \mathrm{ha}{ }^{-1}\right)$. The control of pests, diseases, and weed was conducted similarly in all treatments according to management practices of each sugarcane mill. The daily temperature, solar radiation, rainfall, wind speed, and relative humidity data were collected from a meteorological station next to the experimental fields. The climatological water balance (Fig. 3) was computed according to the methods proposed by Thornthwaite and Mather [35].

\section{Soil measurements and calculations}

Soil sampling was performed after the harvesting of the fourth ratoon in July 2018 (Fig. 2). Composite soil samples were collected from the sugarcane row and inter-row positions at 0-5-, 5-10-, 10-20-, and 20-40-cm depths for SOC concentration analysis. The samples were air-dried, after $10 \mathrm{~g}$ was ground, sieved using a $0.150-\mathrm{mm}$ mesh sieve, and then analyzed by dry combustion using a carbon analyzer - LECO CN 628. In order to calculate SOC stocks, undisturbed soil samples were collected using volumetric rings (diameter $0.05 \mathrm{~m} \times$ height $0.05 \mathrm{~m}$ ) for bulk density (BD) determination. Then, the samples were weighed before and after oven drying at $105^{\circ} \mathrm{C}$ to determine dry-weight basis. The $\mathrm{BD}\left(\mathrm{Mg} \mathrm{dm}^{-3}\right)$ was calculated by dividing the soil dry mass by the cylinder volume.

SOC stocks for the 0-10- and 0-40-cm layers were calculated as the sum of the stocks for each depth: 0-5, 5-10, 10-20, and $20-40 \mathrm{~cm}$. In order to adjust SOC stocks to an equivalent soil mass, the $\mathrm{BD}$ of the baseline characterization (Table 1) was used as a reference to adjust the depths of the treatments CTNR, CTMR, CTTR, RTNR, RTMR, and RTTR according to the methodology described in Ellert and Bettany [36]. The rates of SOC loss and accumulation ( $\mathrm{Mg} \mathrm{C} \mathrm{ha}{ }^{-1}$ year $\left.^{-1}\right)$ associated with each treatment (CTNR, CTMR, CTTR, RTNR, RTMR, RTTR) in the last year of evaluation were calculated for the $0-10$ and $0-40-\mathrm{cm}$ depths according to equation: (SOC stock $_{\text {final }}$ (fourth ratoon) $-\mathrm{SOC}$ stock $\left._{\text {initial (baseline) }}\right) / 5$ years, in order to represent changes in SOC stocks $\left(\mathrm{Mg} \mathrm{ha}^{-1}\right)$ induced by the straw removal levels and tillage systems in relation to the reference SOC stock before the trial setup in 2012 .

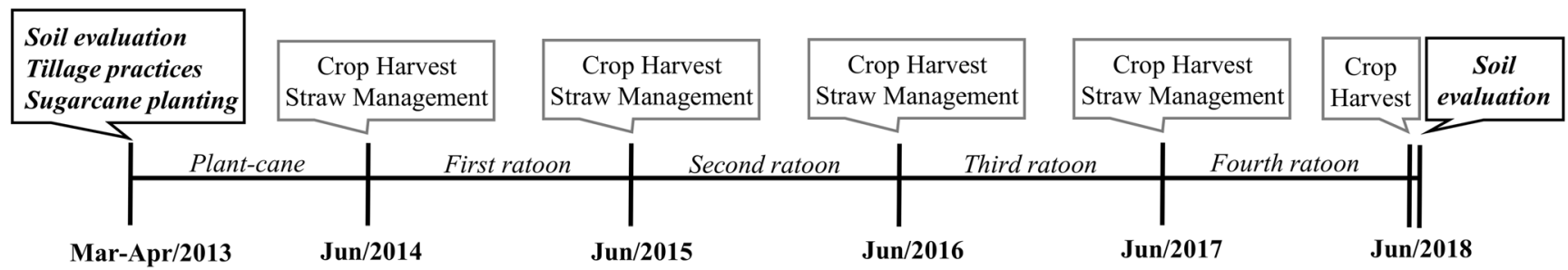

Fig. 2 Timeline description of the installation, harvesting, straw management, and soil evaluation of the experimental areas 


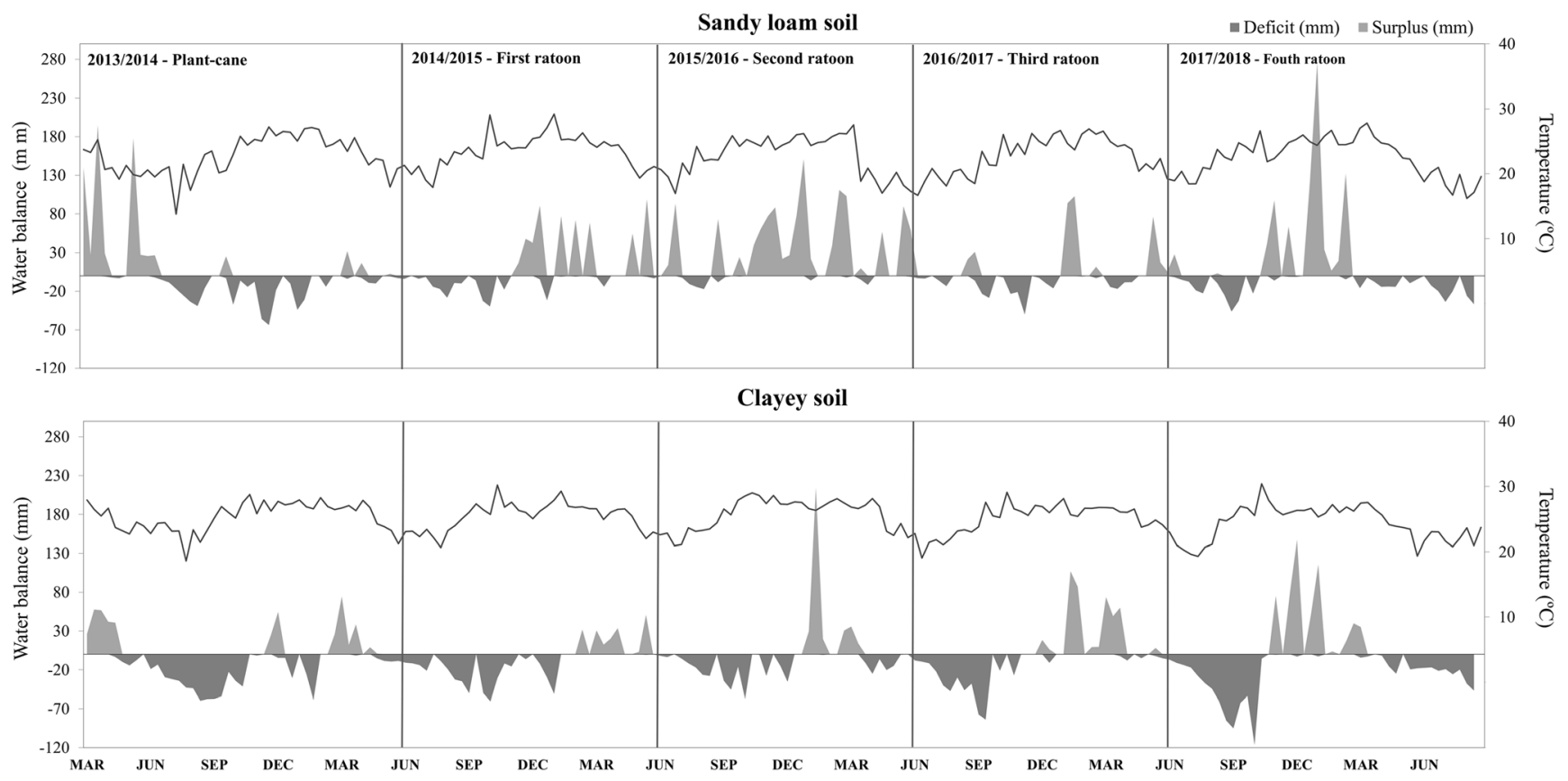

Fig. 3 Water balance accounted for the two sites (sandy loam soil—Quatá/SP; clayey soil—Quirinópolis/GO) during the sugarcane crop cycle

In order to explore a deeper understanding of SOC accumulation induced by the cumulative effects of different amounts of straw, samples for microbial biomass C (MBC) and $\beta$-glucosidase activity analyses were collected in the RTNR, RTMR, and RTTR treatments. The analyses of MBC were performed by the fumigation-extraction method [37] from a $0-10-\mathrm{cm}$ soil depth. For the same soil samples, the activity of $\beta$-glucosidase enzyme was evaluated according to Tabatabai [38]. The microbial quotient $\left(q_{\text {MIC }}\right)$ expressed by the ratio of MBC to SOC is related to how much SOC is immobilized in the microbial biomass (i.e., a measure of carbon availability). The microbial quotient $\left(q_{\mathrm{MIC}}\right)$ was calculated by the ratio between MBC and SOC [39].

\section{Measurements of sugarcane stalk yields}

Sugarcane crop was annually harvested between June and July for 5 years of the study in Quatá/SP and Quirinópolis/ GO. Each plot was harvested by a mechanical harvester and stalk yields were computed for the four central rows through an instrumented truck equipped with a loading cell (used exclusively for experiments).

\section{Statistical analyses}

After the normality verification according to the Shapiro-Wilk test at $5 \%$ of significance and homogeneity of variance by the Oneill and Mathews test, the data was subjected to analysis of variance (ANOVA) to assess differences among the six treatments of straw removal under tillage systems and the average results were compared using Tukey's test $(p<0.05)$. The statistical analysis was performed according to a randomized block design with six treatments and four repetitions. In order to isolate the effects of tillage system and straw removal on sugarcane yields, a separate comparison between the means of CT and RT systems was performed to obtain the effects regardless of straw removal levels, as well as for comparisons between means of straw removal levels regardless of tillage systems. Regression analyses were performed to explore the relationships between SOC stocks and straw inputs in both tillage systems in the $0-10-\mathrm{cm}$ soil depth. All statistical analyses were performed using the R Development Core Team [40].

\section{Results}

\section{SOC concentration and stocks and annual rates of SOC accumulation/loss}

The data indicated that SOC concentration was reduced along the soil profile, with concentrations varying from 1.9 to $7.8 \mathrm{~g}$ $\mathrm{kg}^{-1}$ in the sandy loam soil and 13.3 to $29.4 \mathrm{~g} \mathrm{~kg}^{-1}$ in the clayey soil. High levels of straw removal in both tillage systems reduced SOC concentration in the $0-5-$ and $20-40-\mathrm{cm}$ depth in both soils (Fig. 4).

Tillage systems and straw removal levels significantly affected SOC concentration in both soils $(p<0.05)$. In sandy loam soil, the treatment RTNR was different from CTTR by $3.1 \mathrm{~g} \mathrm{~kg}^{-1}$, while the other treatments did not show any differences $(p<0.05)$. Similar patterns were observed in the clayey soil, where RTNR showed higher SOC concentration 
Fig. 4 SOC concentration (g $\left.\mathrm{kg}^{-1}\right)$ to a $40-\mathrm{cm}$ depth $(0-5,5-$ $10,10-20$, and $20-40 \mathrm{~cm})$ under tillage systems coupled with straw removal levels (CTNR, CTMR, CTTR, RTNR, RTMR, RTTR) in the sandy loam (a) and clayey (b) soils. Data are means from four sampling replicates. Bars refer to the least significant difference between data and asterisk indicates significant differences among the treatments $(p<0.05)$

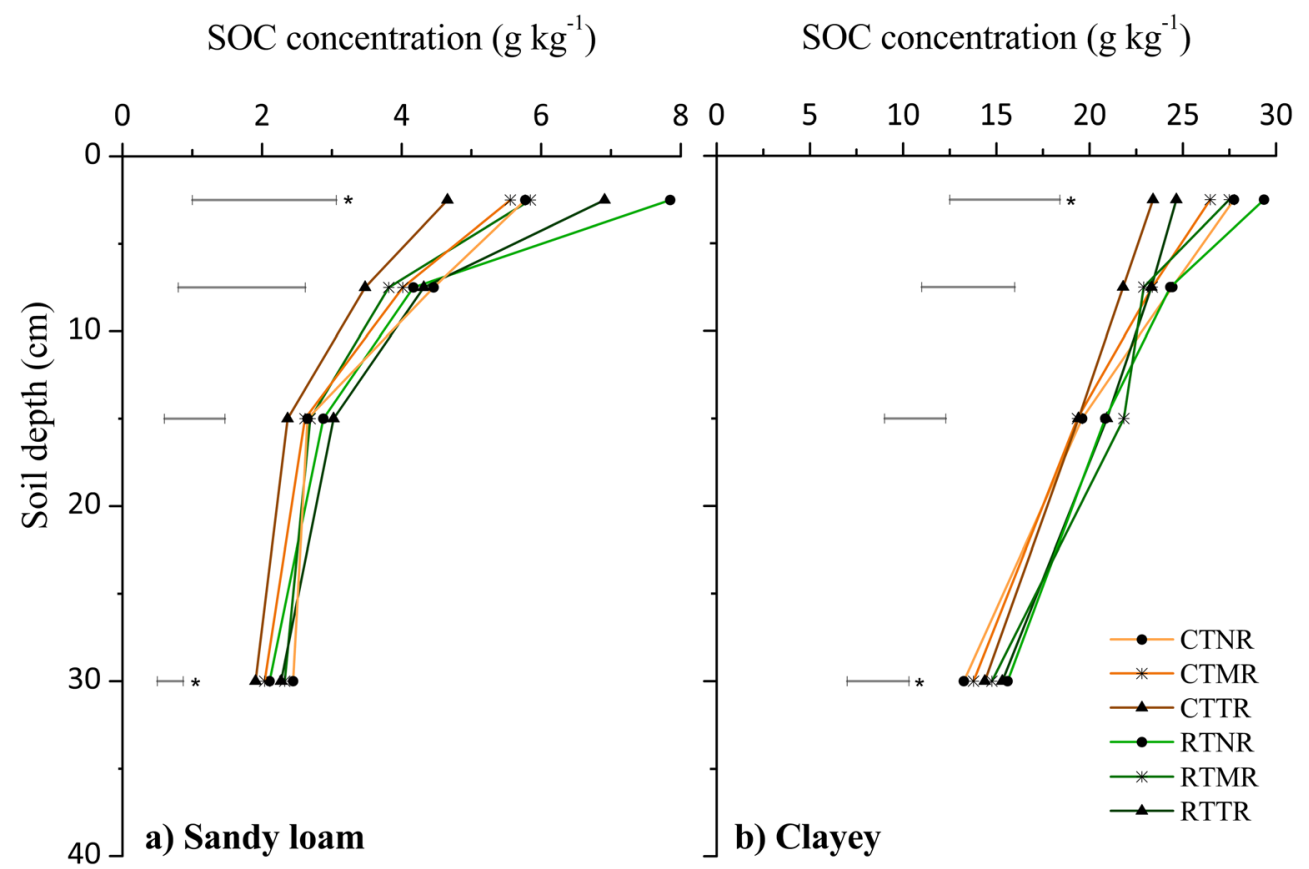

relative to CTTR $(p<0.05)$. Changes in SOC concentration in the $20-40 \mathrm{~cm}$ tended to be consistent with the surface layer. SOC was significantly higher for RTNR and RTMR treatments compared to CTMR and CTTR in the sandy loam soil. Meanwhile, SOC differences in the clayey soil presented higher values $\left(3.7 \mathrm{~g} \mathrm{~kg}^{-1}\right)$ in RTTR than CTNR treatment.

The data obtained herein indicate that significant depletions of SOC stocks were evident when the straw was removed from the field in both soils in the top layer (Fig. 5). For sandy loam soil, straw removal levels did not show differences under CT, but SOC stocks in RTMR and RTTR were lower than RTNR $(p<0.05)$. In addition, SOC stock under RTNR was superior by $1.9 \mathrm{Mg} \mathrm{ha}^{-1}$ than the mean values of RTMR, CTNR, CTMR, and CTTR. For clayey soil, SOC stock under RTNR was higher than CTTR by $5.8 \mathrm{Mg} \mathrm{ha}^{-1}$. At the $0-40-$ cm depth, significant effects on SOC stocks were evident only in the sandy loam, showing similar SOC stocks under RTNR, RTTR, and CTNR, which were $5.1 \mathrm{Mg} \mathrm{ha}^{-1}$ higher than CTTR.

Our findings indicate that performing RT at sugarcane planting led to positive SOC sequestration rather than disturbing the soil through CT in the $0-40-\mathrm{cm}$ profile, even when all the straw was removed from the field (Fig. 6). In clayey soil, the adoption of RT resulted in average rates of SOC accumulation $(0-40 \mathrm{~cm})$ of $1.64,1.03$, and $1.43 \mathrm{Mg} \mathrm{C}$ $\mathrm{ha}^{-1}$ year $^{-1}$ for RTNR, RTMR, and RTTR compared with baseline, respectively. In contrast, CT systems showed average rates of SOC loss of $-0.05,-0.18$, and $-0.50 \mathrm{Mg} \mathrm{C} \mathrm{ha}^{-1}$ year $^{-1}$ for CTNR, CTMR, CTTR, respectively. In sandy loam soil, the RT treatments presented SOC accumulation (0-40 $\mathrm{cm}$ ) of $0.39,0.06$, and $0.42 \mathrm{Mg} \mathrm{C} \mathrm{ha}^{-1}$ year $^{-1}$ for RTNR, RTMR, and RTTR, respectively. Analyzing CT treatments, only CTNR showed a positive SOC accumulation rate (0.23 $\mathrm{Mg} \mathrm{C} \mathrm{ha}^{-1}$ year $^{-1}$ ), while CTMR and CTTR exhibited SOC losses of -0.19 and $-0.62 \mathrm{Mg} \mathrm{C} \mathrm{ha}^{-1}$ year $^{-1}$, respectively.

The cumulative straw returned to the field for four consecutive years increased SOC stocks in both sites (Fig. 7). Straw inputs after sugarcane harvests described significant linear regression model of SOC changes $(0-10 \mathrm{~cm})$ under CT treatment in sandy loam soil, while under CT and RT in clayey soil $(p<0.05)$, respectively. The results suggested that about $95 \mathrm{~kg}$ $\mathrm{C} \mathrm{ha}{ }^{-1}$ was retained in the soil for each $\mathrm{Mg}$ of sugarcane straw returned in the clayey under both $\mathrm{CT}$ and RT treatments compared with $55 \mathrm{~kg} \mathrm{C} \mathrm{ha}^{-1}$ in the sandy under CT treatment.

\section{Microbial biomass $C$ and enzymatic activity}

Analyzing the effects of RT system under levels of straw removal, soil biological attributes were significantly responsive in the clayey soil (0-10 cm) (Fig. 8). The magnitude of MBC and b-glucosidase activity response was directly proportional to the decrease of straw removal levels. For instance, RTTR system showed decreased MBC of $32 \%$ and $21 \%$ in comparison with RTMR and RTNR, respectively. The b-glucosidase presented the highest activity in RTNR (45.8 $\mathrm{mg} \mathrm{kg}^{-1}$ soil) and RTMR (41.3 $\mathrm{mg} \mathrm{kg}^{-1}$ soil) than RTTR (19.6 $\mathrm{mg} \mathrm{kg}^{-1}$ ).

Considering the relationship between $\mathrm{MBC}$ and $\mathrm{SOC}$ stocks, the values of MBC:SOC ratio $\left(q_{\mathrm{MIC}}\right)$ found in sandy loam soil showed variations between RTNR, RTMR, and RTTR treatments of $1.3,1.8$, and $1.4 \%$, respectively, while the $q_{\text {MIC }}$ in clayey soil decreased as a result of the increase in straw removal levels $(2.9,2.7$, $2.2 \%$ ) (data not shown), respectively. 

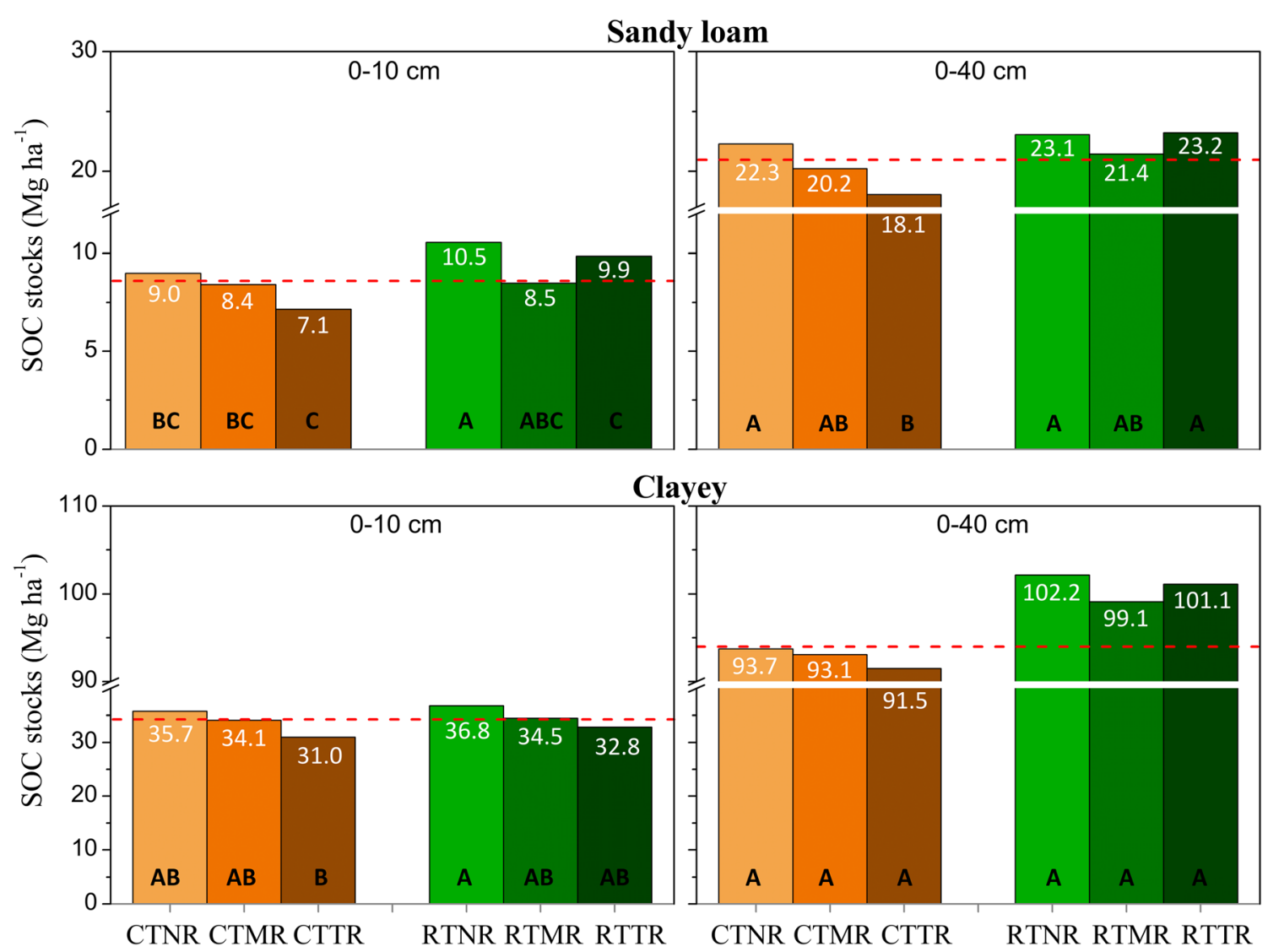

Clayey

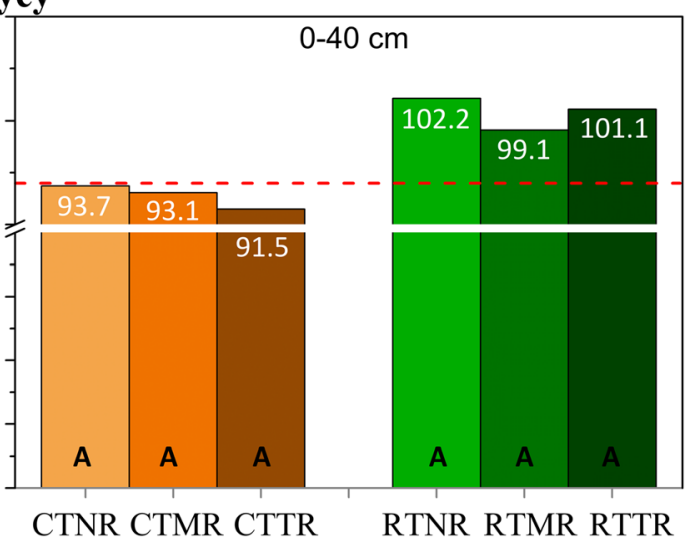

Fig. 5 SOC stocks $\left(\mathrm{Mg} \mathrm{ha}^{-1}\right)$ at the $0-10$ and $0-40$-cm soil layers under tillage systems coupled with straw removal (CTNR, CTMR, CTTR, RTNR, RTMR, RTTR) in the sandy loam and clayey soils. Data are

\section{Sugarcane yield}

Sugarcane yield $\left(\mathrm{Mg} \mathrm{ha}^{-1}\right)$ declined over the crop cycle in the sandy loam soil $(p<0.05)$ (Suppl. Table S1). There was no significant effect of tillage systems and straw removal on the average sugarcane yield in the sandy loam soil over a 5-year means from four sampling replicates. Means followed by the same letter do not indicate significant difference by Tukey test $(p<0.05)$

period $(p>0.05)$. In the clayey soil, the yield of CTMR, CTTR, and RTTR treatments showed a substantial reduction in relation to other treatments $(p<0.05)$.

Isolating the effects of each treatment group (Fig. 9), the tillage systems did not show any changes in sugarcane yield in the sandy loam soil, but an average increase of $7 \mathrm{Mg} \mathrm{ha}^{-1}$ was

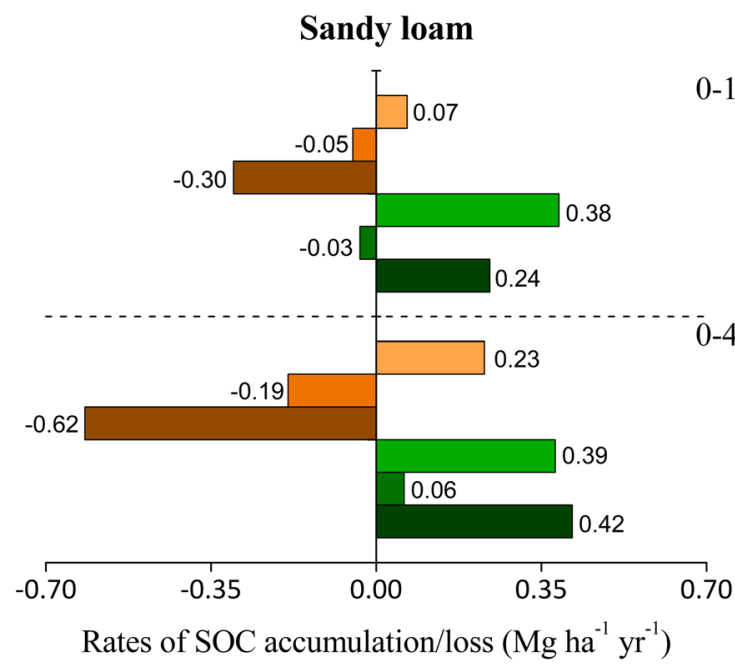

Fig. 6 Annual rates of SOC stocks accumulation and loss $\left(\mathrm{Mg} \mathrm{ha}^{-1}\right.$ year $^{-1}$ ) at soil depths of $0-10$ and $0-40 \mathrm{~cm}$ under tillage systems

\section{Clayey}
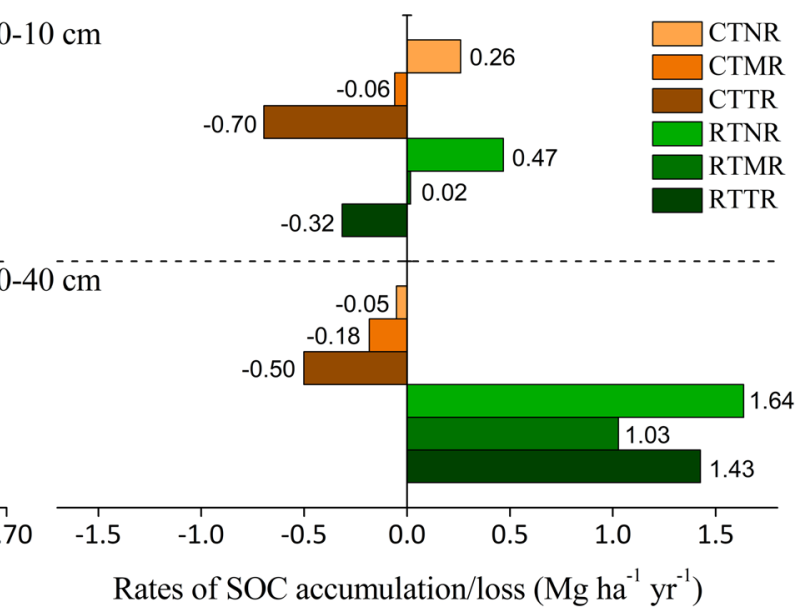

coupled with straw removal (CTNR, CTMR, CTTR, RTNR, RTMR, RTTR) in the sandy loam and clayey soils 
a) Sandy loam

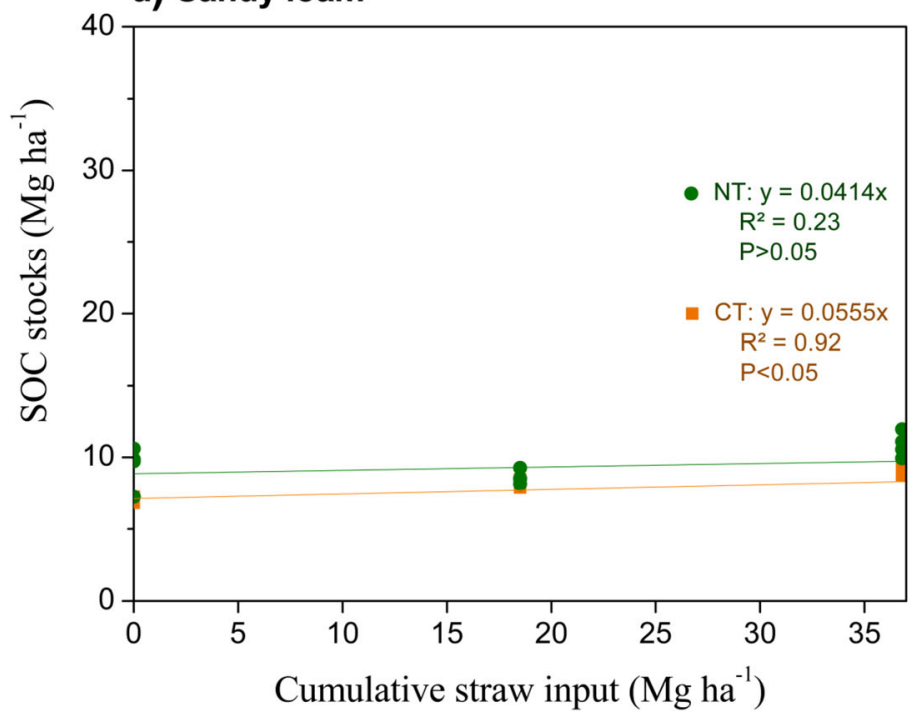

Fig. 7 Relationship between the 4-year cumulative straw inputs (in dry basis) and SOC stocks $(0-10 \mathrm{~cm})$ under tillage systems (CT-

observed for RT in relation to $\mathrm{CT}$ in clayey soil. Considering the average yield as a function of straw removal levels, no changes were also noticed in sandy loam soil. In contrast, NR treatment exhibited higher sugarcane yield in comparison with MR and TR treatments in clayey soil, with increases of 11 and $18 \mathrm{Mg} \mathrm{ha}^{-1}$, respectively.

\section{Discussion}

\section{Effects of tillage and straw removal on SOC stocks}

Tillage practices and annual inputs of crop residues strongly influence SOC balance in agricultural areas. Sugarcane is a

\section{b) Clayey}

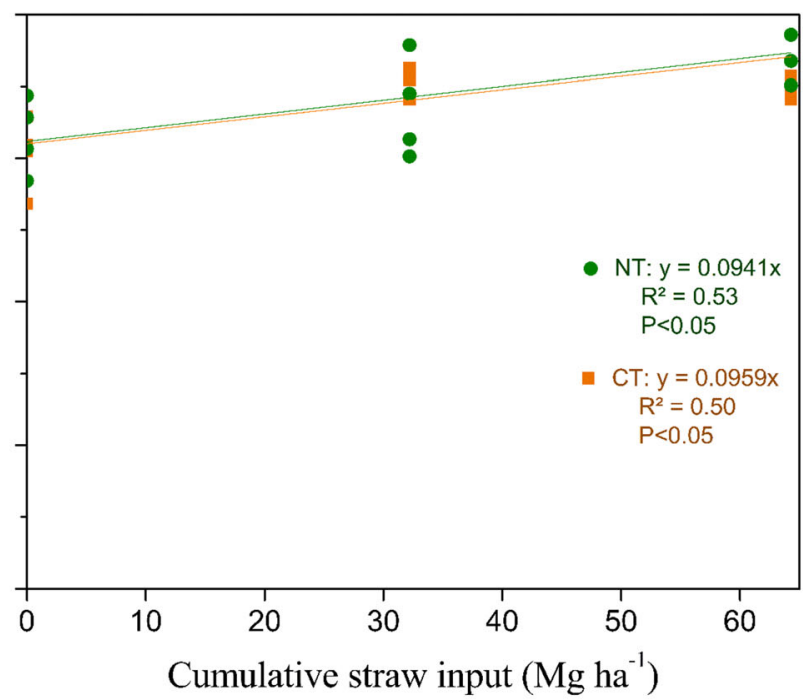

conventional tillage and RT-reduced tillage) in the sandy loam and clayey soils. $p<0.05$ indicates linear regression is significant

crop that produces large amounts of straw per year and soil tillage generally occurs once every 5 to 6 years [14]. In most sugarcane areas, tillage operations (i.e., plowing, harrowing, and subsoiling) are still commonly used in the replanting period to alleviate soil compaction. However, due to heavy traffic of machinery, the effectiveness of these strategies for soil compaction mitigation usually has a temporary effect and requires regular recurrences [41]. In our study, the straw removal rates on SOC stocks showed different patterns when associated with tillage systems. The moderate and total removal of straw associated with the $\mathrm{CT}$ system resulted in a significant reduction of SOC stocks in both soils. On the other hand, the impact of straw removal rates on SOC stocks under the RT system was less detrimental in the clayey soil. These

\section{Sandy loam}

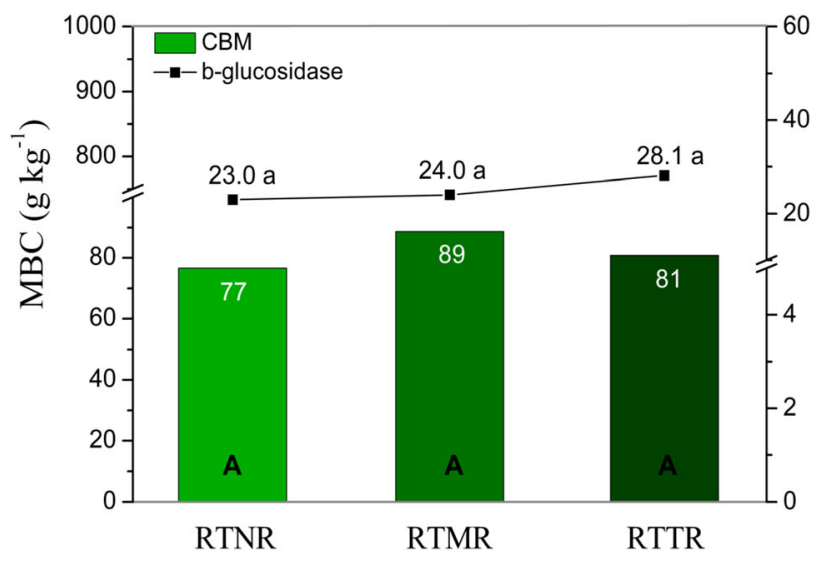

Fig. 8 Effects of straw removal (RTNR, RTMR, RTTR) on b-glucosidase activity (black lines) and microbial biomass $\mathrm{C}$ (green bars) after 4 years in the sandy loam and clayey soils. Data are means from four sampling replicates. Means followed by the same uppercase letter do not indicate
Clayey

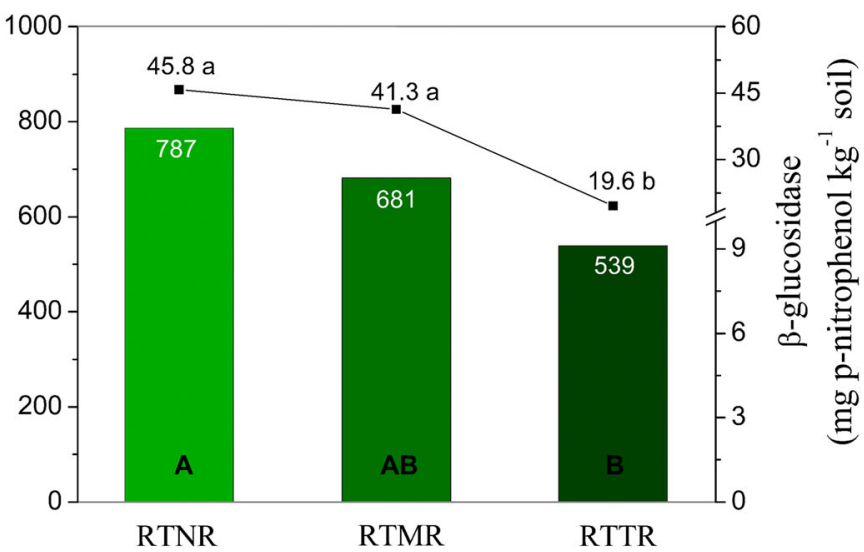

significant difference of microbial biomass $\mathrm{C}$ and under same lowercase letter do not indicate significant difference of b-glucosidase activity by Tukey test $(p<0.05)$ 


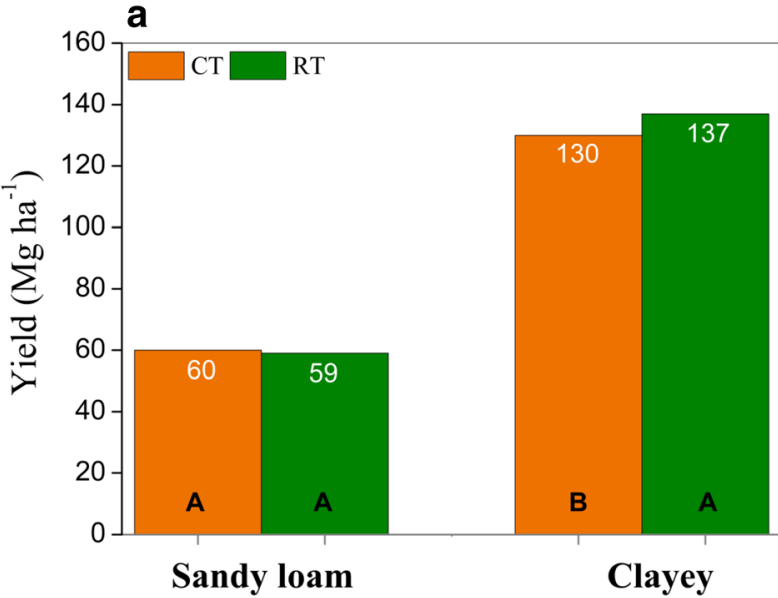

Fig. 9 Effects of tillage management systems (a) and straw removal levels (b) on the average sugarcane yield $\left(\mathrm{Mg} \mathrm{ha}^{-1}\right)$ after five harvests in the sandy loam and clayey soils. Data are means from four replicates.

differences in SOC stocks should be associated with the impact of soil disturbance by tillage on reducing SOC stocks and thus forming a smaller SOC baseline under CT, which resulted in less SOC accumulation in areas under straw cover in the subsequent crop cycles. When fragmented, fresh residues (straw/roots/rhizomes) are incorporated in soils with nutrient shortages and available reactive binding sites are increased between soil particles and SOC; it is likely that the decomposition of protected SOC might be accelerated [42]. Depletion of SOC induced by tillage is also related to higher soil temperature and aeration, thus creating an improved environment for microbial activity and leading to reductions of the most labile C stored in both inter- and intra-aggregates [43]. However, a more stable environment under RT is maintained since less SOC is lost during the sugarcane replanting period, and consequently, a high baseline is sustained with straw additions. Other important factors influencing SOC stock under RT may be attributable to the reduction of soil temperature [44], decreasing soil microbial respiration. Moreover, RT may promote better soil conditions for soil biota and roots system and thus actively contribute to the conservation of soil particle aggregation, water and air retention/flow, and less soil erosion $[19,45]$.

Considering the effects of tillage systems on SOC stocks regardless of straw removal levels, the average SOC stocks found under $\mathrm{CT}$ decreased by $1 \mathrm{Mg} \mathrm{Cha}{ }^{-1}$ compared to $\mathrm{RT}$ in the sandy loam soil, and by $2.1 \mathrm{Mg} \mathrm{C} \mathrm{ha}^{-1}(0-10 \mathrm{~cm}$ layer) and $8 \mathrm{MgC} \mathrm{ha}^{-1}(0-40 \mathrm{~cm})$ in the clayey, respectively (Fig. 5). Our results are aligned with other studies that observed SOC losses under CT of $3.8 \mathrm{Mg} \mathrm{C}^{-1}$ relative to RT, thereby making RT a feasible strategy to reduce SOC losses [43]. Our findings indicate that a conversion from CT to NT system without straw removal would result in SOC gains of 0.31 and $0.21 \mathrm{Mg} \mathrm{C} \mathrm{ha}^{-1}$ year $^{-1}$ in the $0-10 \mathrm{~cm}$ for the sandy loam and clayey soils, respectively (Fig. 6). Similarly, small changes in b

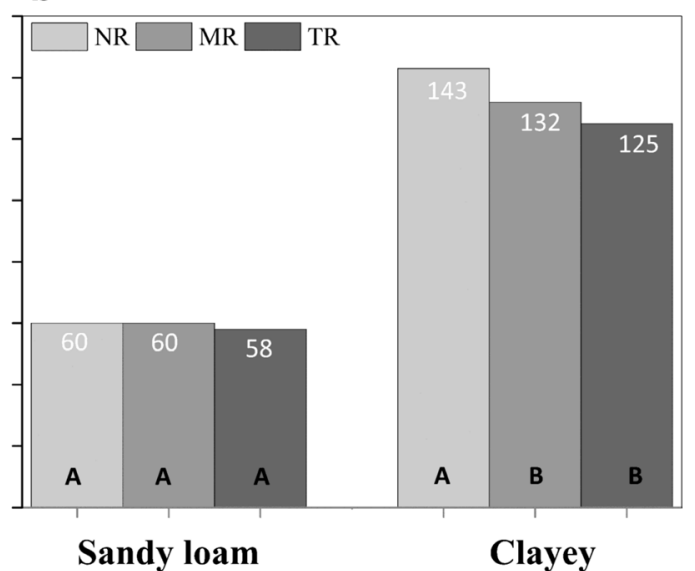

Datasets of the treatments used to obtain the average sugarcane yields are shown in the supplementary material (Table 1S). Means followed by same letters do not indicate significant difference by Tukey test $(p<0.05)$

SOC rates were observed for the $0-40-\mathrm{cm}$ layer in the sandy loam soil, but greater accumulation (1.59 $\mathrm{Mg} \mathrm{C} \mathrm{ha}^{-1}$ year $^{-1}$ ) was observed in clayey soil. In a pioneer study in Brazil, Segnini et al. [28] isolated the effects of straw cover and tillage systems on SOC stocks in sugarcane fields. According to the authors, the adoption of $\mathrm{CT}$ with straw retention resulted in SOC accumulation rates of $0.67 \mathrm{Mg} \mathrm{C}^{-1}$ year $^{-1}$, while the adoption of RT accumulated more than double (1.63 Mg C $\mathrm{ha}^{-1}$ year $\left.^{-1}\right)$. Therefore, only the maintenance of sugarcane straw in the field does not guarantee significant increases in SOC stocks over time, since tillage operations during sugarcane field renovation can result in huge soil $\mathrm{CO}_{2}-\mathrm{C}$ emissions and much of the SOC accumulated during the sugarcane cycle (plant cane and ratoons) could be lost at some weeks after tillage $[25,46]$.

In general, the magnitude of changes in SOC stocks depended on the cumulative amount of straw returned to the soil (Fig. 7). Considering a mean $\mathrm{C}$ concentration of $440 \mathrm{~g}$ $\mathrm{kg}^{-1}$ of straw [8], the regression of cumulative straw returns against measured increases in SOC stocks suggested that about $22 \%$ of $\mathrm{C}$ inputs were retained in the clayey soil under both tillage systems compared with $13 \%$ in the sandy loam under CT system. Our results are similar to those reported by Robertson \&Thorburn [47], who observed a C retention rate of $13 \%$ during 5 years with straw maintenance in sugarcane fields in Australia. The relationship between the increase of SOC stocks and the input of straw is well documented in the literature for sugarcane $[10,13,14,48,49]$ and corn fields [1, $50,51]$. But, the advantages of straw maintenance on the soil go beyond of SOC accretion, given its importance in the fertility of highly weathered tropical soils, since it contributes to SOM formation, which plays an important role in improving cation exchange capacity in these soils [52]. Indirect benefits of straw cover in preserving water availability could also have contributed to soil $\mathrm{C}$-input, highlighting the proper conditions 
to exploration and growth of sugarcane biomass roots [53] and increased microbial biomass activity, which is one of labile $\mathrm{C}$ components present in the SOM [47]. Moreover, C-input from crop residues can be critical to improve soil nutrient recycling in sandy loam soils, which accumulate smaller proportions of $\mathrm{C}$ into the soil and are prone to losing SOC, thus favoring the preservation of a good soil functioning on a long-term basis.

The treatment RTTR showed higher SOC stocks compared with baseline. Although straw contributes to a greater biomass $\mathrm{C}$-input in sugarcane fields, the effect of roots system remained from previous cycle may also have contributed to SOC accretion under the RT system [14, 54]. Additionally, considering the straw effect of the previous sugarcane cycle in these areas, it is likely that the straw previously maintained on the soil surface in the RT treatment may also have influenced $\mathrm{C}$-input where all straw was removed, thus increasing SOC stocks. Aligned with these findings, predictions using modeling simulations have shown that part of SOC losses induced by straw removal can be compensated under RT as a feasible strategy in Brazil [13].

Greater SOC stocks in response to RT adoption are related to increased soil microbial activity [55]. Based on the ratio of MBC:SOC $\left(\mathrm{q}_{\mathrm{MIC}}\right)$, the data provided evidences of SOC accumulation under lower levels of straw removal. This infers that higher organic $\mathrm{C}$ was immobilized in the microbial biomass under higher amounts of straw deposited on the soil surface (e.g., RTMR and RTNR). The maintenance of soil covered with straw under RT is likely to enhance nutrient and water availability for microbial and plant growth, which led to higher MBC content $[47,49]$. Some studies reported the increase of $\mathrm{MBC}$ as a function of sugarcane straw retention in the field [11, 56] and under RT after cover crop [57]. It could be inferred that more labile $\mathrm{C}$ fraction derived of longstanding residues was biologically available to microbial respiration, which provided increasing MBC and $\beta$-glucosidase activity, thus increasing soil quality under these treatments $[15,58]$. In sandy loam soil, the low $\beta$-glucosidase values reported by Lopes et al. [59] are likely related to the low SOC content as a substrate for the enzyme, which is associated to the weak interactions between sand fraction and organic $\mathrm{C}$ and low initial C concentrations. Similarly, the low $\beta$-glucosidase values [59] observed in clayey soil may be related to the recent intensive tillage agriculture in this area of Brazilian Cerrado (12 years with sugarcane production), which could contain complex quantity and quality of plants residues returned to soil that may have affected the degradation rate of cellulose compounds [60].

Our findings reinforce the importance of maintaining straw cover on the soil surface for the control of the labile components of SOM (microbial biomass) and SOC stocks. In this context, the combination of straw cover and RT showed to be a sustainable management strategy to mitigate SOC losses with a large potential for additional SOC sequestration.

\section{Effects of tillage systems and straw removal on sugarcane yield}

Improved sugarcane production is narrowly dependent on soil health and the adoption of sustainable management practices [61]. Several strategies have been conducted for identifying best management practices of sustainable straw removal to enhance sugarcane yield and crop longevity. The effects of tillage systems on sugarcane yields show that CT and RT over a 5-year cycle presented similar average yields in the sandy loam soil, but RT exhibited yields of $7 \mathrm{Mg} \mathrm{ha}^{-1}$ year $^{-1}$ higher relative to $\mathrm{CT}$ in the clayey soil (Fig. 9). These results are very important for the context of straw management decisions for bioenergy production, since the CT system is still the main tillage used in sugarcane areas in Brazil.

In areas of high productive potential (clayey soil), the mean yield under CTTR and CTMR $\left(\sim 8 \mathrm{Mg} \mathrm{ha}^{-1}\right)$ considerably reduced sugarcane yield. The maintenance of straw on the soil surface in the clayey soil was crucial to sustaining high sugarcane yields levels by preserving soil moisture, especially at an early stage of the crop growth, in which drought conditions are observed during the four ratoon cycles (Fig. 2). Other studies have demonstrated that straw retention increases sugarcane yield $[10,61]$ which may be attributed to the improvements of soil quality $[16,62]$. Low sugarcane yields under high removal of sugarcane straw are explained by the impaired capacity of ratoons to regrowth and uptake water/ nutrients after harvest [63]. The soil covered with straw recycles nutrients from the previous cycle to the growing plant and is likely to reduce soil erosion, water runoff/evaporation, which increases the water use efficiency in the superficial layers [18] where the most quantity of sugarcane roots is confined $[64,65]$. Although the mean yield under RTTR was higher than CTMR and CTNR, this management strategy may not guarantee that best soil functions will be preserved without the long-term benefits of straw retention.

In this study, sugarcane yield in sandy loam soil was not responsive to the straw removal levels (Fig. 8), which could be related to its condition of better aeration, highwater infiltration and low fertility that may have not favored crop production. But a concern regarding straw removal under this soil type conditions is the cover protection that diminishes the potential for soil erosion losses [12]. The presence of straw on soil surface along the year may be useful in this area for other reasons such as regulating soil temperature variations, maintaining soil physical conditions, fauna/microbial activities, nutrient cycling, and SOC, which may reflect in yield gains $[5,9]$. A significant yield decline along the crop cycle was observed in sandy loam area (Suppl. Table 1), which may be associated to the natural decline of productive capacity of sugarcane ratoons and damages in the stool caused by heavy mechanized traffic [66]. 


\section{Implications of tillage systems and straw removal in sugarcane sector}

Opinions about the straw removal recommendations are based on diverse arguments, including edaphoclimatic conditions and management practices [5]. As important as assessing the amount of sugarcane straw on soil surface, considering tillage systems were also critical to fully account for managementinduced changes on SOC stocks and sugarcane yields for industrial uses. Our findings endorse the importance of adopting a sugarcane system based on reduced tillage combined with sustainable straw management strategies for enhancing SOC stocks while still improving or not compromising sugarcane yields. The CT system is currently performed during sugarcane planting to attenuate soil compaction as an immediate solution, but if CT does not justify in terms of yield gains or even prevent SOC losses, why should it be implemented? Significant reductions in SOC stocks and sugarcane yields tended to be clearly site-specific under CT combined with moderate and total straw removal (Figs. 5 and 9). However, while inappropriate management practices may deplete soil C stocks, adoption of best management practices that reduce soil $\mathrm{C}$ losses are key opportunities to further enhance the $\mathrm{C}$ savings of Brazilian sugarcane ethanol production in areas under straw removal [13]. The benefits of straw retention may also be important in view of the sugarcane expansion in the Brazilian Cerrado region, where more restrictive environments are usually common in terms of soil fertility and climatic conditions. Special attention should be given for sandy soils, in which RT and avoidance of sugarcane straw removal are crucial issues to maintaining SOC stocks. Additionally, concerns regarding the environmental costs with fuel and tractor hours during sugarcane planting under $\mathrm{CT}$ system have not been approached in this study, but the RT adoption as an alternative to CT reduces diesel consumption by avoiding some tillage operations and, consequently, could provide a $22.7 \%$ reduction of GHG balance of sugarcane production [67].

Our findings support the idea that sugarcane systems with straw removal should consider potential RT effect on SOC accumulation to meet reduction of Brazilian GHG emissions target. If we consider that the best scenario for potential SOC accumulation was RTNR in both soils $(0-40 \mathrm{~cm})$, the conversion of sugarcane areas from a traditional scenario in Brazil under CTNR to RTNR system could provide a mean net SOC accumulation of $0.9 \mathrm{Mg} \mathrm{ha}^{-1}$ year $^{-1}$ (difference in SOC stocks between CTNR and RTNR). Assuming that most of the sugarcane cultivated areas in Brazil (9 million ha) is currently cultivated under CTNR system, the adoption of a RTNR system could result in additional SOC accumulation of $8.1 \mathrm{Tg} \mathrm{C}$ year $^{-1}$ into the soil, which corresponds to a soil $\mathrm{C}$ sequestration capacity of $29.73 \mathrm{Tg} \mathrm{CO}_{2}$ year $^{-1}$ from the atmosphere. Therefore, the adoption of RT would mean offsetting part of the total GHG emissions associated with Brazilian agricultural activities in sugarcane areas. An effective strategic plan for implementing RT system with a sustainable straw removal would represent a relevant contribution to achieve the ambitious targets of reducing GHG emissions by $37 \%$ in 2025 announced by the Brazilian government in the last Paris climate agreement within the United Nations Framework Convention on Climate Change (COP21).

Future studies should focus on management practices to maximize the quality of the RT system to improve SOC conservation under straw removal scenarios. Considering that RT performed in sugarcane fields represents a considerable soil disturbance in the crop row of $12.5 \%$ of the surface layer (Fig.1) for opening the planting furrows in comparison with grain crops, studies should focus on improving technology that reduces soil disaggregation during sugarcane planting by adopting, for example, planting of sugarcane pre-sprout systems [68]. Other important practices include the use of rotation with leguminous crops, controlled traffic farming, double crop row spacing, and adjustments of machines width. The recent study demonstrates longer sugarcane longevity when the combination of procedures is implemented in conjunction with accurate guidance of machine traffic in the field, which will preserve the physical quality of the crop row and enhance cane yields [69]. Therefore, the adoption of RT could provide a moderate straw removal for bioenergy production with SOC storage sustenance and potentially extra revenue by increasing stalk yield and saving agricultural inputs (e.g., fertilizers and fuels).

\section{Conclusions}

Can RT be a feasible strategy to "prevent" SOC loss induced by straw removal while sustaining sugarcane yields? Conclusions drawn from this study suggest that RT system with a moderate straw cover in the soil could potentially provide sustainable use of parts of the straw from the field for bioenergy purposes while enhancing SOC stocks and sustain sugarcane yields over the crop cycle in both soils. The adoption of RT could be a management strategy to offset the adverse effects of straw removal in the sugarcane sector. The microbial indicators in the clayey soil point out to increases in SOC turnover under RT with moderate and no straw removal, which could lead to an increase in SOC stocks. The straw removal in areas under CT system intensifies SOC losses and does not reflect in higher sugarcane yield compared to RT. In clayey soil, CT system combined with moderate and total removal of straw showed SOC losses $(0-40 \mathrm{~cm})$ at a rate of 0.18 and $0.50 \mathrm{Mg} \mathrm{ha}^{-1}$ year $^{-1}$, respectively. Similarly, SOC losses in sandy loam soil under CTTR reached up $0.62 \mathrm{Mg}$ ha $^{-1}$ year $^{-1}$ and SOC accumulation $\left(0.23 \mathrm{Mg} \mathrm{ha}^{-1}\right.$ year $\left.^{-1}\right)$ was observed only when all the straw was left on the soil surface. 
Sugarcane yield was not affected by tillage systems in the sandy loam soil, but CT under total and moderate removal of straw decreased cane yields in clayey soil.

Based on the mid-term empirical data, these findings highlight the need to decrease soil disturbance in traditional CT, suggesting RT as a feasible tillage strategy for more sustainable sugarcane production. We advocate that additional modeling efforts on long-term SOC dynamics are needed to validate these findings to credibly assess the longstanding impacts to make a safer and accurate decision about the magnitude and levels at which straw can be sustainably removed.

Acknowledgments This research was supported by the Sugarcane Renewable Electricity project - SUCRE/PNUD (grant number BRA/ $10 / \mathrm{G} 31$ ) and the National Council for Scientific and Technological Development-CNPq (grant 406922/2013-6). ROB is grateful to the Sao Paulo Research Foundation - FAPESP for providing the research grant (grant 2017/23978-7). ST thanks the Brazilian Federal Agency for Support and Evaluation of Graduate Education - (CAPES/CNPEM program) for providing her doctoral fellowship (grant 88882.143503/201701). We would like to thank the LNBR technician group for all the support in the field and laboratory activities, and Quatá and Boa Vista Mills for providing the experimental sites and the logistical support during the fieldwork.

\section{Compliance with ethical standards}

Conflict of Interest The authors declare that they have no conflict of interest.

Open Access This article is distributed under the terms of the Creative Commons Attribution 4.0 International License (http:// creativecommons.org/licenses/by/4.0/), which permits unrestricted use, distribution, and reproduction in any medium, provided you give appropriate credit to the original author(s) and the source, provide a link to the Creative Commons license, and indicate if changes were made.

\section{References}

1. Karlen DL, Beeler LW, Ong RG, Dale BE (2015) Balancing energy, conservation, and soil health requirements for plant biomass. J Soil Water Conserv 70:279-287. https://doi.org/10.2489/jswc.70.5.279

2. MME (2017) Ministry of Mines and Energy. Renova Bio Programme. http://www.mme.gov.br/web/guest/secretarias/ petroleo-gas-natural-e-combustiveis-renovaveis/programas/ renovabio/principal. Accessed 19 Mar 2019

3. iNDC Brazil (2015) Intended nationally determined contribution towards achieving the objective of the United Nations Framework Convention on Climate Change. Federative Republic of Brazil. http://www.itamaraty.gov.br/images/ed_desenvsust/ BRAZILiNDC- english.pdf. Accessed 25 Jan $201 \overline{9}$

4. CONAB (2018) Acompanhamento da safra brasileira de cana-deaçúcar. In: Companhia Nacional de Abastecimento (Ed.), Terceiro Levantamento - Safra 2018/19, 75p. http://www.conab.gov.br Accessed 17 Jan 2019

5. Carvalho JLN, Nogueirol RC, Menandro LMS, Bordonal RDO, Borges CD, Cantarella H, Franco HCJ (2017a) Agronomic and environmental implications of sugarcane straw removal: a major review. Glob Change Biol Bioenergy 9:1181-1195. https://doi. org/10.1111/gcbb.12410

6. Mello FFC, Cerri CEP, Davies CA, Holbrook NM, Paustian K, Maia SMF, Galdos MV, Bernoux M, Cerri CC (2014) Payback time for soil carbon and sugar-cane ethanol. Nat Clim Chang 4:605-609. https://doi.org/10.1038/nclimate2239

7. Leal MRL, Galdos MV, Scarpare FV, Seabra JE, Walter A, Oliveira CO (2013) Sugarcane straw availability, quality, recovery and energy use: a literature review. Biomass Bioenergy 53:11-19. https:// doi.org/10.1016/j.biombioe.2013.03.007

8. Menandro LMS, Cantarella H, Franco HCJ, Kölln OT, Pimenta MTB, Sanches GM, Rabelo SC, Carvalho JLN (2017) Comprehensive assessment of sugarcane straw: implications for biomass and bioenergy production. Biofuels Bioprod Biorefin 11: 488-504. https://doi.org/10.1002/bbb.1760

9. Cherubin MR, Oliveira DMDS, Feigl BJ, Pimentel LG, Lisboa IP, Gmach MR et al (2018) Crop residue harvest for bioenergy production and its implications on soil functioning and plant growth: A review. Sci Agric 75:255-272. https://doi.org/10.1590/1678-992x2016-0459

10. Bordonal RO, Menandro LMS, Barbosa LC, Lal R, Milori DMBP, Kolln OT et al (2018) Sugarcane yield and soil carbon response to straw removal in south-central Brazil. Geoderma 328:79-90. https://doi.org/10.1016/j.geoderma.2018.05.003

11. Souza RA, Telles TS, Machado W, Hungria M, Tavares Filho J, Guimarães MF (2012) Effects of sugarcane harvesting with burning on the chemical and microbiological properties of the soil. Agric Ecosyst Environ 155:1-6. https://doi.org/10.1016/j.agee.2012.03. 012

12. Sousa GB, Martins Filho MV, Matias SSR (2012) Soil, organic matter and nutrientes losses by water erosion in a slope with sugarcane straw, in Guariba, State of São Paulo. Engenharia Agrıcola 32: 490-500. https://doi.org/10.1590/S0100-69162012000300008

13. Oliveira DMS, Williams S, Cerri CEP, Paustian K (2017) Predicting soil $\mathrm{C}$ changes over sugarcane expansion in Brazil using the DayCent model. Glob Change Biol Bioenergy 9:1436-1446. https://doi.org/10.1111/gcbb.12427

14. Carvalho JLN, Hudiburg TW, Franco HCJ, DeLucia EH (2017b) Contribution of above- and belowground bioenergy crop residues to soil carbon. Glob Change Biol Bioenergy 9:1333-1343. https:// doi.org/10.1111/gcbb.12411

15. Naresh RK, Timsina J, Bhaskar S, Gupta RK, Singh AK, Dhaliwal SS, Rathore RS, Kumar V, Singh P, Singh SP, Tyagi S, Kumar S, Mahajan NC (2017) Effects of tillage, residue and nutrient management on soil organic carbon dynamics and its fractions, soil aggregate stability and soil carbon sequestration: a review. EC Nutrition 12:53-80

16. Castioni GA, Cherubin MR, Menandro LMS, Sanches GM, de Oliveira Bordonal R, Barbosa LC, Franco HCJ, Carvalho JLN (2018) Soil physical quality response to sugarcane straw removal in Brazil: a multi-approach assessment. Soil Tillage Res 184:301309. https://doi.org/10.1016/j.still.2018.08.007

17. Liao Q, Wei GP, Chen GF, Liu B, Huang DL, Li YR (2014) Effect of trash addition to the soil on microbial communities and physicochemical properties of soils and growth of sugarcane plants. Sugar Tech 16:400-404. https://doi.org/10.1007/s12355-013-0296-8

18. Cheong LRN, Teeluck M (2016) The practice of green cane trash blanketing in the irrigated zone of Mauritius: effects on soil moisture and water use efficiency of sugarcane. Sugar Tech 18:124-133. https://doi.org/10.1007/s12355-015-0374-1

19. Corrêa STR, Barbosa LC, Menandro LMS, Scarpare FV, Reichardt $\mathrm{K}$, de Moraes LO et al (2019) Straw removal effects on soil water dynamics, soil temperature, and sugarcane yield in south-central Brazil. BioEnergy Res:1-15. https://doi.org/10.1007/s12155-01909981-w 
20. Campos LHF, Carvalho SJP, Christoffoleti PJ, Fortes C, Silva JS (2010) Sistemas de manejo da palhada influenciam acúmulo de biomassa e produtividade da canade-açúcar (var. RB855453). Acta Sci Agron 32:345-350. https://doi.org/10.4025/actasciagron. v32i2.3703

21. Gonzaga LC, Carvalho JLN, de Oliveira BG, Soares JR, Cantarella $\mathrm{H}$ (2018) Crop residue removal and nitrification inhibitor application as strategies to mitigate $\mathrm{N}_{2} \mathrm{O}$ emissions in sugarcane fields. Biomass Bioenergy 119:206-216. https://doi.org/10.1016/j. biombioe.2018.09.015

22. Clay DE, Alverson R, Johnson JM, Karlen DL, Clay S, Wang MQ, ... \& Westhoff S (2019) Crop residue management challenges: a special issue overview. Agron J 111:1-3. doi:https://doi.org/10. 2134/agronj2018.10.0657

23. Scarlat N, Fahl F, Lugato E, Monforti-Ferrario F, Dallemand JF (2019) Integrated and spatially explicit assessment of sustainable crop residues potential in Europe. Biomass Bioenergy 122:257269. https://doi.org/10.1016/j.biombioe.2019.01.021

24. Sousa Junior JGDA, Cherubin MR, Oliveira BG, Cerri CE, Cerri CC, Feigl BJ (2018) Three-year soil carbon and nitrogen responses to sugarcane straw management. Bio Energy Res 11:249-261. https://doi.org/10.1007/s12155-017-9892-x

25. Cerri CC, Galdos MV, Maia SMF, Bernoux M, Feigl BJ, Powlson D, Cerri CEP (2011) Effect of sugarcane harvesting systems on soil carbon stocks in Brazil: an examination of existing data. Eur J Soil Sci 62:23-28. https://doi.org/10.1111/j.1365-2389.2010.01315.x

26. Garside AL, Watters TS, Berthelsen JE, Sing NJ, Bell MJ (2004) Comparisons between conventional and alternative sugarcane farming systems which incorporate permanent beds, minimum tillage, controlled traffic and legume fallow. Proc Aust Soc Sugar Cane Technol:26

27. Chagas MF, Bordonal RO, Cavalett O, Carvalho JLN, Bonomi A, La Scala N Jr (2016) Environmental and economic impacts of different sugarcane production systems in the ethanol biorefinery. Biofuel Bioprod Biorefin 10:89-106. https://doi.org/10.1002/bbb. 1623

28. Segnini A, Carvalho JLN, Bolonhezi D, Milori DMBP, Silva WTL, Simões ML, Cantarella H, Maria IC, MartinNeto L (2013) Carbon stock and humification index of organic matter affected by sugarcane straw and soil management. Sci Agric 70:321-326. https://doi. org/10.1590/S0103-90162013000500006

29. Lorenz K, Lal R, Ehlers K (2019) Soil organic carbon stock as an indicator for monitoring land and soil degradation in relation to United Nations' sustainable development goals biomass and bioenergy. Land Degrad Dev 30:1-15. https://doi.org/10.1002/ldr. 3270

30. Wiesmeier M, Urbanski L, Hobley E, Lang B, von Lützow M, Marin-Spiotta E et al (2019) Soil organic carbon storage as a key function of soils-a review of drivers and indicators at various scales. Geoderma 333:149-162. https://doi.org/10.1016/j.geoderma.2018. 07.026

31. Soil Survey Staff (2014) Keys to soil taxonomy, 12th edn. USDANRCS, Washington DC, p 372

32. Thornthwaite CW (1948) An approach toward a rational classification of climate. Geogr Rev 38:55-94

33. Van Raij B, Andrade JC, Cantarella H, Quaggio JA (2001) Análise Química para Avaliação da Fertilidade de Solos Tropicais. Instituto Agronômico, Campinas

34. Blake GR, Hartge KH (1986) Bulk density. In: Klute A (ed) Methods of soil analysis. Part 1. Physical and mineralogical methods, 2nd edn. American Society of Agronomy, Madison, pp 363-375

35. Thornthwaite CW, Mather JR (1955) In: Centerton NJ (ed) The water balance. Drexel Institute of Technology, Laboratory of Climatology 104p. (Publications in Climatology, vol. VIII, n. 1)
36. Ellert BH, Bettany JR (1995) Calculation of organic matter and nutrients stored in soils under contrasting management regimes. Can J Soil Sci 75:529-538. https://doi.org/10.4141/cjss95-075

37. Vance ED, Brookes PC, Jenkinson DS (1987) An extraction method for measuring microbial biomass C. Soil Biol Biochem 19:703707. https://doi.org/10.1016/0038-0717(87)90052-6

38. Tabatabai MA (1994) Soil enzymes. In: Page AL, Miller EM, Keeney DR (eds) Methods of soil analysis, Part 2, Chemical and microbiological properties, vol 1. American Society of Agronomy, pp 903-947

39. Sparling GP (1992) Ratio of microbial biomass carbon to soil organic-carbon as a sensitive indicator of changes in soil organicmatter. Aust J Soil Res 30:195-207. https://doi.org/10.1071/ SR9920195

40. R Development Core Team (2015) R: a language and environment for statistical computing. R Foundation for Statistical Computing, Vienna, Austria Available at: http://www.R-project.org.

41. Chamen WT, Moxey AP, Towers W, Balana B, Hallett PD (2015) Mitigating arable soil compaction: a review and analysis of available cost and benefit data. Soil Tillage Res 146:10-25. https://doi. org/10.1016/j.still.2014.09.011

42. Six J, Feller C, Denef K, Ogle SM, De Moraes JC, Albrecht A (2002) Soil organic matter, biota and aggregation in temperate and tropical soils - effects of no-tillage. Agronomie 22:755-775. https://doi.org/10.1051/agro:2002043

43. La Scala NJ, Bolonhezi D, Pereira GT (2006) Short-term soil $\mathrm{CO}_{2}$ emission after conventional and reduced tillage of a no-till sugar cane area in southern Brazil. Soil Tillage Res 91:244-248. https:// doi.org/10.1016/j.still.2005.11.012

44. Lal R (1989) Conservation tillage for sustainable agriculture: tropics versus temperate environments. In Adv Agron, v 42, pp 85197. Academic Press.

45. Moraes MT, Debiasi H, Carlesso R, Franchini JC, da Silva VR, da Luz FB (2017) Age-hardening phenomena in an oxisol from the subtropical region of Brazil. Soil Tillage Res 170:27-37. https://doi. org/10.1016/j.still.2017.03.002

46. La Scala Junior N, De Figueiredo EB, Panosso AR (2012) A review on soil carbon accumulation due to the management change of major Brazilian agricultural activities. Braz J Biol 72:775-785. https://doi.org/10.1590/S1519-69842012000400012

47. Robertson FA, Thorburn PJ (2007) Management of sugarcane harvest residues: consequences for soil carbon and nitrogen. Aust $\mathrm{J}$ Soil Res 45:13-23. https://doi.org/10.1071/SR06080

48. Thorburn PJ, Meier EA, Collins K, Robertson FA (2012) Changes in soil carbon sequestration, fractionation and soil fertility in response to sugarcane residue retention are site-specific. Soil Tillage Res 120:99-111. https://doi.org/10.1071/SR06080

49. Leite LFC, Sagrilo E, de Araújo ASF, de Souza HA (2018) Shortterm effect of sugarcane straw on soil organic carbon pools. J Agric Sci 10:8. https://doi.org/10.5539/jas.v10n8p405

50. Blanco-Canqui H, Lal R (2007) Soil and crop response to harvesting corn residues for biofuel production. Geoderma 141:355-362. https://doi.org/10.1016/j.geoderma.2007.06.012

51. Guzman JG, Al-Kaisi MM (2014) Residue removal and management practices effects on soil environment and carbon budget. Soil Sci Soc Am J 78:609-623. https://doi.org/10.2136/sssaj2013.10. 0426

52. Fontes MPF, Alleoni LRF (2006) Electrochemical attributes and availability of nutrients, toxic elements, and heavy metals in tropical soils. Sci Agric 63:589-608. https://doi.org/10.1590/S010390162006000600014

53. Aquino GSD, Medina CDC, Junior P, Leonel A, Santos LO, Cunha ACB et al (2015) Root system and productivity of sugarcane ratoon associated to different quantities of straw. Pesq Agropec Bras 50: 1150-1159. https://doi.org/10.1590/S0100-204X2015001200004 
54. Carvalho JLN, Otto R, Franco HCJ, Trivelin PCO (2013) Input of sugarcane post-harvest residues into the soil. Sci Agric 70:336-344. https://doi.org/10.1590/S0103-90162013000500008

55. Moraes Sá JC, Tivet F, Lal R, Briedis C, Hartman DC, dos Santos JZ, dos Santos JB (2014) Long-term tillage systems impacts on soil $\mathrm{C}$ dynamics, soil resilience and agronomic productivity of a Brazilian Oxisol. Soil Tillage Res 136:38-50. https://doi.org/10. 1016/j.still.2013.09.010

56. Paredes FP Jr, Portilho IIR, Mercante FM (2015) Microbiological attributes of the soil under cultivation of sugar cane with and without burning straw. Semina: Ciências Agrárias 36:151-163 (in Portuguese, with abstract in English). https://doi.org/10.5433/ 1679-0359.2015v36n1p151

57. Tenelli S, Otto R, Castro SAQ, Bohórquez Sánchez CE, Sattolo TMS, Kamogawa MY, Pagliari PH, Carvalho JLN (2019) Legume nitrogen credits for sugarcane production: implications for soil $\mathrm{N}$ availability and ratoon yield. Nutr Cycl in Agroec 1-16: 307-322. https://doi.org/10.1007/s10705-019-09979-y

58. Blair N (2000) Impact of cultivation and sugarcane green trash management on carbon fractions and aggregate stability for a Chromic Luvisol in Queensland, Australia. Soil Tillage Res 55: 183-191. https://doi.org/10.1016/S0167-1987(00)00113-6

59. Lopes AAC, Sousa DMG, Chaer GM, Junior FBR, Goedert WJ, Mendes IC (2013) Interpretation of microbial soil indicators as a function of crop yield and organic carbon. Soil Sci Soc Am J 77: 461-472. https://doi.org/10.2136/sssaj2012.0191

60. Peixoto RS, Chaer GM, Franco N, Reis FB, Mendes JIC, Rosado AS (2010) A decade of land use contributes to changes in the chemistry, biochemistry and bacterial community structures of soils in the Cerrado. Antonie Van Leeuwenhoek 98:403-413. https://doi. org/10.1007/s10482-010-9454-0

61. Garside AL, Bell MJ, Robotham BG, Magarey RC, Stirling GR (2005) Managing yield decline in sugarcane cropping systems. Int Sugar J 107:16-26

62. Satiro LS, Cherubin MR, Safanelli JL, Lisboa IP, da Rocha Junior PR, Cerri CEP, Cerri CC (2017) Sugarcane straw removal effects on
Ultisols and Oxisols in south-central Brazil. Geoderma Reg 11:8695. https://doi.org/10.1016/j.geodrs.2017.10.005

63. Aquino GS, Medina CC, Costa DC, Shahab M, Santiago AD (2017) Sugarcane straw management and its impact on production and development of ratoons. Ind Crop Prod 102:58-64. https://doi. org/10.1016/j.indcrop.2017.03.018

64. Otto R, Silva AP, Franco HCJ, Oliveira ECA, Trivelin PCO (2011) High soil penetration resistance reduces sugarcane root system development. Soil Tillage Res 117:201-210. https://doi.org/10.1016/ j.still.2011.10.005

65. Barbosa LC, de Souza ZM, Franco HCJ, Otto R, Neto JR, Garside AL, Carvalho JLN (2018) Soil texture affects root penetration in Oxisols under sugarcane in Brazil. Geoderma Reg 13:15-25. https://doi.org/10.1016/j.geodrs.2018.03.002

66. Braunack MV, Garside AL, Magarey RC (2012) Reduced tillage planting and the long-term effect on soil-borne disease and yield. Soil Tillage Res 120:85-91. https://doi.org/10.1016/j.still.2011.11. 002

67. Bordonal RO, De Figueiredo EB, Aguiar DA, Adami M, Theodor Rudorff BF, La Scala N (2013) Greenhouse gas mitigation potential from green harvested sugarcane scenarios in São Paulo State, Brazil. Biomass Bioenergy 59:195-207. https://doi.org/10.1016/j. biombioe.2013.08.040

68. Landell MGA, Campana MP, Figueiredo P (2013) Sistema de multiplicação de cana-de-açúcar com uso de mudas pré-brotadas (MPB), oriundas de gemas individualizadas. 2. ed. rev. Campinas: Instituto Agronômico, 16p. (Documentos IAC, 109)

69. Esteban DAA, de Souza ZM, Tormena CA, Lovera LH, de Souza Lima E, de Oliveira IN, de Paula Ribeiro N (2019) Soil compaction, root system and productivity of sugarcane under different row spacing and controlled traffic at harvest. Soil Tillage Res 187:60-71. https://doi.org/10.1016/j.still.2018.11.015

Publisher's Note Springer Nature remains neutral with regard to jurisdictional claims in published maps and institutional affiliations. 